\title{
IUMRS Seeks Nominees for 2004 Sōmiya Award for International Collaboration
}

The International Union of Materials Research Societies (IUMRS) is seeking nominations for the annual Sōmiya Award for International Collaboration in Materials Research, which recognizes research on real materials conducted by a research team whose members are drawn from at least two continents. The submission deadline is February 20, 2004.

Sōmiya Award recipients are selected by the IUMRS Commission on Awards. The honorees receive an award commemorating the occasion and complimentary registration to the annual IUMRS International Conference where they present their work. This year, the conference will be held at the 2004 Materials Research Society Spring Meeting/IUMRS 9th International Conference on Electronic Materials (IUMRS-ICEM 2004), April 12-16, 2004, in San Francisco.
The following criteria are used by the Commission on Awards for selection: - The team to be honored must have collaborated across at least two continents (e.g., North America, Europe, Asia, and Australia) at some time during the last decade; - The collaborative work must be of the highest quality and have received recognition from the international materials community; and

- The impact the work has had on technology or society is a major factor.

IUMRS was established in 1991 as an international association of technical groups and societies that have an interest in promoting interdisciplinary materials research. The annual Somiya Award is named in honor of Shigeyuki Sōmiya, professor emeritus of the Tokyo Institute of Technology and former dean at Teikyo University of Science and Engineering.
Sōmiya has received the MRS Medal and the Japanese Scientific Academic Award.

Sōmiya spent his postgraduate years in the United States and embarked on a series of collaborative research and exchange visits in many countries, starting in 1969 with the U.S.-Japan Workshop in Ceramicsthe first in materials science. He also pursued joint work with colleagues in Europe and brought many international materials gatherings to Japan.

The Dutch-Chinese research team of Klaas de Groot (IsoTis NV) and FuZhai Cui (Tsinghua University) received the 2003 Sōmiya Award for their investigation of biomimetic calcium phosphate composites.

Information about the award and submission forms are available at www. iumrs.org.

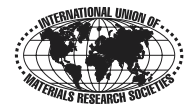

